\title{
Pendidikan Keterampilan Kerja Bagi Warga Berkebutuhan Khusus Melalui Pelayanan Keliling di Pedesaan
}

\author{
Haryanto \\ PLB FIP UNY, email: haryanto_plb@uny.ac.id
}

\begin{abstract}
Abastrak: Penelitian ini bertujuan untuk mengetahui intensitas, efektivitas, hubungan antara intensitas pelayanan model dengan keterampilan, dan dampak model bagi warga berkebutuhan khusus. Subjek penelitian warga berkebutuhan khusus usia produktif. Lokasi penelitian di wilayah Gunungkidul, jenis penelitian Research and Development, dilaksanakan tahun 2008-2009. Teknik pengumpulan data menggunakan observasi, intervu, demonstrasi, dan tes. Analisis data menggunakan pendekatan kuantitatif dan kualitatif. Data kuantitatif diolah dengan program LISREL, data kualitatif dianalisis melalui model interaktif. Hasil penelitian menunjukkan bahwa keterampilan subjek dapat berubah dengan arah positif sesuai dengan berubahnya intensitas, terdapat perubahan perilaku warga berkebutuhan khusus melalui partisipasi masyarakat, didukung sarana dan prasarana yang memadai, untuk menjaga keterampilan kerja yang optimal, selain membangun intensitas juga perlu dijaga keakuratan kerja dan ketepatan waktu, dampak hasil model bagi warga berkebutuhan khusus tidak sekedar memiliki keterampilan kerja tetapi secara psikologis mereka merasa diperhatikan, dihargai, hal ini menumbuhkan semangat hidup, berkarya, dan hidup mandiri.
\end{abstract}

Kata kunci: pendidikan keterampilan kerja, warga berkebutuhan khusus, dan pelayanan keliling

\begin{abstract}
This study aimed to investigate the intensity and effectiveness, the relationship between the intensity of a model service and skills, the effectiveness of the model service, and the effect of the model on people with special needs in terms of the work accuracy level with accurate products, work time accuracy, and work perfection with good results. This study was a research and development study. The research subjects were people with special needs in the productive age who have not held permanent jobs. The study was conducted in the area of Gunungkidul in the period of 2008-2009. The data were collected through observations, interviews, demonstrations, and tests. The data were analyzed by means of the mixed methods involving the quantitative and qualitative approaches. The quantitative data were analyzed by LISREL and the qualitative data by the interactive model. The result showed that the subject's skill may changed tin a positive direction in accordance with intensity, the attitude change among people with special needs occur throgh optimal work, beside building intensity also need to remain the work accuracy and the time puretually, the impact of the model result for the people with special needs not only about having the work skill but phsycologically they felt noted, respected, and it raises their life spirit, to work and live independently.
\end{abstract}

Key words: work skills education, people with special needs, and mobile service

\section{Pendahuluan}

Untuk mendapatkan layanan pendidikan bagi warga berkebutuhan khusus, termasuk mereka yang tinggal di pedesaan, di Indonesia telah terdapat beberapa model, yaitu 1) segregasi (pendidikan khusus) yang meliputi SLB konvensional dan SDLB; 2) mainstreaming (pendidikan terpadu); 3) di rumah sakit atau lembaga perawatan; 4) model inklusif. Berbagai model penyelenggaraan pendidikan bagi warga ber- kebutuhan khusus yang tinggal di pedesaan masih terdapat berbagai kendala atau kelemahan.

Memperhatikan hasil penelitian Haryanto (2005:165) terdapat beberapa kendala dalam pelaksanaan model pendidikan bagi warga berkebutuhan khusus di pedesaan, yaitu: 1) masih sangat terbatasnya guru spesialis, psikolog, fisioterapis, dokter spesialis, sosiolog, dan sebagainya; 2) masih sangat terbatasnya sarana dan peralatan khusus sesuai dengan kebutuhan 
anak berkebutuhan khusus; misalnya ruang keterampilan khusus, ruang dan alat latihan artikulasi, ruang dan peralatan latihan fisioterapi, dan sebagainya; 4) berkaitan dengan kesiswaan; kenyataan di lapangan, populasi anak berkebutuhan khusus menyebar di pelosok desa, sementara gedung sekolah untuk anak berkebutuhan khusus yang telah berdiri kebanyakan berada di kota Kabupaten atau Kecamatan. Kenyataan yang ada, jumlah warga berkebutuhan khusus yang belum tertampung di Sekolah Luar Biasa masih banyak. Mereka tersebar di daerah pedesaan sulit dijangkau sarana transportasi.

Model pendidikan bagi warga berkebutuhan khusus yang sedang dikembangkan oleh pemerintah saat sekarang adalah inklusif. Pendidikan inklusif dipandang akan berhasil meningkatkan mutu sekolah dan pendidikan bagi warga berkebutuhan khusus. Peningkatan mutu sekolah merupakan persiapan yang sangat baik untuk pendidikan inklusif, tetapi sering kali kurang tepat untuk benar-benar menginklusikan kelompok anak yang termarjinalkan, termasuk warga berkebutuhan khusus.

Berbagai model penanganan pendidikan bagi warga berkebutuhan khusus yang telah diselenggarakan oleh pemerintah selama ini kurang memiliki intensitas dan efektivitas. Pemerintah nampaknya menghadapi kesulitan dalam menangani warga berkebutuhan khusus yang jumlahnya relatif kecil menyebar di pedesaan, tetapi secara akumulatif untuk suatu wilayah kecamatan relatif besar. Keadaan sosial ekonomi keluarga umumnya miskin, kesadaran dan kepedulian masyarakat kepada warga berkebutuhan khusus masih rendah, di pedesaan kurang tenaga profesional yang dapat menangani warga berkebutuhan khusus. Bagi anak berkebutuhan khusus yang telah selesai menempuh pendidikan di SLB atau sekolah formal lainnya mereka umumnya kurang memiliki keterampilan kerja, karena sheltered-workshop yang ada di SLB belum berfungsi secara maksimal. Akibatnya, banyak anak berkebutuhan khusus walaupun telah tamat pendidikan setingkat SMTP dan SMTA mereka tetap masih menggantungkan orang lain atau kurang dapat mandiri, karena materi pendidikan yang diberikan oleh sekolah, yang dapat membangun kompetensi keterampilan kerja sangat terbatas.
Dalam hal pelayanan model pendidikan bagi warga berkebutuhan khusus di pedesaan, hasil penelitian Mc. Laughlin (2003: 59) menyimpulkan, perlu ada kebijakan untuk penyelenggaraan sekolah keterampilan kerja bagi warga berkebutuhan khusus. Misalnya, melalui model integrasi di masyarakat atau pendidikan pada umumnya. Yang diusulkan adalah perlu adanya model Regional Resource Center (RRC). Bagaimana pun, kebijakan untuk implementasi dan administrasi program tidak boleh memaksa para siswa berkebutuhan khusus ke dalam suatu sistem terpisah atau pendidikan khusus yang mengizinkan para guru untuk tidak melepaskan tanggung jawab mereka mendidik para siswa berkebutuhan khusus. Yang sangat menonjol dalam proses pembelajaran pendidikan bagi warga berkebutuhan khusus adalah dengan dikembangkan model IEP (Individual Educational Program), yaitu program pembelajaran yang diindividualkan.

Mencermati berbagai permasalahan dan temuan hasil penelitian yang relevan; melalui model yang dikembangkan ini diharapkan jangkauan layanan pendidikan keterampilan kerja bagi warga berkebutuhan khusus dapat lebih meluas ke wilayah pedesaan. Jika model yang dikembangkan telah teruji tingkat intensitas dan keefektivannya maka diharapkan warga berkebutuhan khusus akan memiliki keterampilan kerja. Pengaruhnya bagi mereka dalam memenuhi kebutuhan hidup tidak selalu menggantungkan kepada orang lain, karena mereka telah memiliki keterampilan kerja dan usaha mandiri di pedesaan.

Mencermati permasalahan yang ditemukan, model penelitian pengembangan ini bertujuan 1) mengetahui intensitas atau kehebatan pelayanan model dilihat dari kinerja organisasi dan manajemen, tingkat partisipasi masyarakat, ketersediaan sarana-prasarana, efektivitas implementasi program aksi, nilai benefits atau manfaat, terhadap pelaksanaan pengembangan model; 2) mengetahui efektivitas model dilihat dari tingkat penguasaan keterampilan warga berkebutuhan khusus, kualitas produk, dan marketable products atau produk yang dipasarkan dalam pengembangan model; 3) mengetahui hubungan intensitas pelayanan model dengan efektivitas model keterampilan kerja bagi warga berkebutuh- 
an khusus melalui pelayanan keliling berbasis partisipasi masyarakat pedesaan terpencil; 4) menghasilkan alternatif kebijakan tentang pengembangan pendidikan keterampilan kerja bagi warga berkebutuhan khusus untuk pemerintah dan lembaga atau instansi terkait yang berkecimpung dalam penanganan warga berkebutuhan khusus.

\section{Kajian Literatur}

\section{Warga Berkebutuhan Khusus}

Batasan tentang warga berkebutuhan khusus sangat bervariasi, tergantung pada sudut pandangnya. Ada yang memberi batasan dari sudut pandang pelayanan sosial, pendidikan, kesehatan atau pekerjaan. Pada dasarnya yang dimaksud warga berkebutuhan khusus atau orang berkelainan adalah seseorang yang mengalami kelainan/kecacatan, baik dalam segi fisik, psikis, mental dan atau sosial. Jumlah mereka di Indonesia relatif cukup besar. Departemen Sosial RI (2005: 22) mengestimasikan sebesar 3\% dari jumlah penduduk mengalami kecacatan atau berkebutuhan khusus.

Warga berkebutuhan khusus mengalami masalah yang disebabkan oleh sikap dan penerimaan keluarga dan masyarakat. Selama ini belum semua anggota keluarga dan masyarakat bersikap positif terhadap penyandang cacat. Kehadiran warga berkebutuhan khusus dianggap masih sebagai anggota/warga kelas dua, bahkan tidak sedikit orang tua yang masih merasa malu dengan kehadiran warga berkebutuhan khusus, karena mereka dianggap sebagai kutukan Tuhan.

Masalah yang dihadapi warga berkebutuhan khusus adalah belum tersedianya fasilitas di masyarakat yang memungkinkan mereka hidup mandiri. Andaikata masyarakat sudah bersikap positif terhadap warga berkebutuhan khusus namun belum tersedia sarana bagi mereka, misalnya belum semua sekolah terbuka bagi mereka, belum semua gedung mempunyai sarana bagi pemakai kursi roda, belum semua sekolah mempunyai toilet khusus bagi warga berkebutuhan khusus.

Sehubungan dengan hal tersebut, perlu dikembangkan suatu model pendidikan keterampilan kerja bagi warga berkebutuhan khusus di pedesaan yang menitikberatkan pada peran serta masyarakat sebagai basis utama dari program. Model kegiatan semacam ini disebut pendidikan keterampilan kerja bagi warga berkebutuhan khusus berbasis masyarakat lewat pelayanan keliling. Melalui program ini diharapkan jangkauan layanan pendidikan keterampilan kerja warga berkebutuhan khusus dapat lebih diperluas ke daerah-daerah pedesaan serta kualiatas layanan pendidikannya dapat lebih meningkat.

Kenapa model pelayanan keliling pendidikan keterampilan kerja bagi warga berkebutuhan khusus harus berbasis masyarakat? Selama ini banyak dijumpai proyek-proyek pemerintah yang datang dari atas, meskipun satu sisi secara fisik mempunyai dampak yang nyata, namun sering dilupakan dampak secara mental. Kegiatan proyek pemerintah tidak dapat memandirikan masyarakat, bahkan cenderung semakin bergantung dan kurang menumbuhkan inisiatif dari bawah, masyarakat menjadi apatis. Karena itu, prosesnya harus dibalik dari bawah melalui proses pendidikan masyarakat secara wajar.

Model pelayanan pendidikan berbasis masyarakat pernah juga dianjurkan oleh Freire (2002: 34) yang menekankan pentingnya penyadaran masyarakat dalam menerapkan pembangunan di pedesaan. Asumsi yang digunakan oleh Freire adalah tidak ada manusia yang dapat belajar sendiri tanpa orang lain, ia belajar bersama, bertindak dan berhubungan dengan dunia mereka. Freire menggambarkan pentingnya kebersamaan dalam membangun masyarakat untuk dapat berhasil dengan baik. Kebersamaan itu dapat dicapai melalui proses penyadaran masyarakat.

Pembangunan menerapkan pendekatan top down akan banyak mengalami kegagalan karena mengesampingkan aspek kesadaran dan kebersamaan. Pendekatan ini juga kurang mengakui adanya potensi dan kebutuhan riil masyarakat (real need). Menurut Goble, Frank G. (1987: 53) seorang tokoh psikologi humanistik justru menekankan pentingnya memahami kebutuhan masyarakat. Manusia akan mampu mengembangkan potensi secara nyata dan optimal jika kebutuhan-kebutuhan dasarnya dapat terpenuhi. Pengertian dan kasih sayang/ rasa aman dan perlindungan, terpenuhi kebutuhan untuk bekerja sama dengan orang lain serta adanya pengakuan akan potensi dan harga diri. 


\section{Pendidikan Keterampilan Kerja}

Pendidikan keterampilan kerja bagi warga berkebutuhan khusus, pada intinya adalah berorientasi pada upaya untuk dapat bekerja, karena kerja merupakan aktivitas dasar dan dijadikan bagian yang esensi dari kehidupan manusia. Dengan demikian kerja dapat memberikan kesenangan, serta makna tersendiri bagi kehidupan manusia, orang dapat hidup dan sekaligus merasa berguna, dibutuhkan dan dikehendaki masyarakatnya.

Model pendidikan keterampilan kerja berbasis masyarakat dalam penelitian ini dikembangkan berdasarkan konsep teoritis pembelajaran keterampilan kerja dari Polloway \& Patton (1993: 97) bahwa setting masyarakat dapat memberikan manfaat yang lebih luas dan bervariasi bagi individu yang berkebutuhan khusus, karena secara otomatis mereka akan berhadapan dan secara langsung menjadi anggota masyarakat. Selama di sekolah, para warga berkebutuhan khusus hanya mendapat sedikit keterampilan kerja produktif, yang tidak dapat disesuaikan dalam kehidupan sehari-hari.

Dalam hal intensitas pelayanan dan partisipasi masyarakat, seperti diungkapkan penelitian Harvey (2001: 46) dapat melalui metode survai. Orang tua para warga berkebutuhan khusus menunjukkan, bahwa intensitas pelayanan pendidikan kurang maksimal. Mereka mempertimbangkan agar anak-anaknya meninggalkan sekolah dikarenakan a) mereka merasa tidak ada perkembangan dan kemajuan di dalam sekolah; b) mereka tidak suka sekolah; c) mereka bosan; d) mereka menikah atau menjadi orang tua; dan e) mereka mempunyai permasalahan tingkah laku. Boe (2006: 24) menjelaskan bahwa dari tahun ke tahun sangat dibutuhkan intensitas pelayanan guru sesuai dengan profesi dan kompetensi untuk mengajar warga berkebutuhan khusus, tetapi dari tahun ke tahun kebutuhan tersebut sangat terbatas. Untuk meningkatkan kualitas dan intensitas layanan guru sesuai dengan kekhususan mengajar bagi warga berkebutuhan khusus perlu adanya sertifikasi, hal ini sesuai dengan tuntutan kompetensi dan dimensi mutu guru.

Usaha untuk mengungkap jumlah warga berkebutuhan khusus yang tinggal di pedesaan dan kondisi pendidikannya dapat dilihat pada penelitian Haryanto (2007: 45) di Kabupaten Gunung Kidul. Hasilnya menunjukkan kurang lebih $80 \%$ warga berkebutuhan khusus usia sekolah, ternyata tidak bersekolah. Di suatu kecamatan, ditemukan sekitar 290 warga berkebutuhan khusus yang umumnya tinggal di rumah masingmasing, atau ikut orang tua, dalam keadaan buta pendidikan dan pekerjaan alias menganggur.

Temuan tersebut membuktikan perlunya pelayanan pendidikan keterampilan kerja bagi warga berkebutuhan khusus yang menyebar di pedesaan melalui model pendidikan efektif. Model pelayanan keliling berbasis partisipasi masyarakat merupakan salah satu alternatif yang perlu diujicobakan. Penelitian Etscheidt. (2006: 87) menunjukkan agar pelayanan pendidikan yang efektif untuk anak-anak muda yang mengalami kecacatan mereka perlukan pendidikan khusus melalui pelatihan tindakan khusus secara individual. Termasuk pelayanan efektif bagi anakanak kecil yang mengalami kecacatan mereka misalnya dalam belajar berjalan. Program untuk sebelum masuk sekolah bagi anak-anak dapat dipilih di dalam suatu model yang efektif adalah IEP (Individual Education Program) program pembelajaran yang diindividualkan. Untuk melaksanakan program tersebut, perlu didukung adanya undang-undang. Hal ini memberikan wacana, bahwa pelayanan pendidikan keterampilan kerja yang paling efektif untuk warga berkebutuhan khusus, adalah pelayanan individual.

Untuk mengungkapkan efektivitas model, Mc Laughlin, (2003: 39) menyelidiki tingkat efektivitas praktik model pendidikan untuk warga berkebutuhan khusus. Model ini membantu meningkatkan para warga berkebutuhan khusus mencapai hasil pendidikan sekolah menengah untuk bekerja atau melanjutkan pendidikan yang lebih tinggi. Corbett, Kitteringham, dan Mc Anespie (1999: 22) menyatakan pendidikan kejuruan atau pelatihan untuk kasus warga berkebutuhan khusus. Mempengaruhi seluruh Negara Eropa untuk menciptakan berbagai efektivitas pelayanan pendidikan.

Arnold and Seekins, (2006: 29) dalam penelitiannya menjelaskan tentang efektivitas melalui laporan kantor sensus bagi semua warga termasuk yang berkebutuhan khusus. Bahwa hambatan warga yang berkebutuhan khusus 
dalam pekerjaan mandiri (14.7\%) dan yang tidak berkebutuhan khusus ( $8 \%)$.

Untuk mengetahui efektivitas model, Peg Lamb (2003: 57) melalui suatu survai di AS yang diselenggarakan oleh Nasional Organisasi ke pada warga berkebutuhan khusus ternyata hanya $29 \%$ yang bekerja penuh di perusahaan. Bullis dan Yovanoff (2006: 58) konsisten dengan value ini dan pada awal 1980 pemerintah Amerika menerapkan transisi initiativeo dengan tujuan meningkatkan pekerjaan dan pengalaman para warga berkebutuhan khusus. Transisi sekarang dipertimbangkan dalam kaitan dengan penyesuaian masyarakat agar hidup lebih luas. Hal ini memberikan gambaran betapa perlu dan pentingnya bagi warga berkebutuhan khusus diberi hak bekerja di perusahaan.

Dalam hal keterampilan kerja bagi warga berkebutuhan khusus, Indiana (1999: 132) menjelaskan konsep model yang diterapkan; siswa harus memiliki satuan keterampilan dan pengetahuan sehingga diterima di dalam karier dan pendidikan teknis. Melalui karier, keterampilan, dan pengetahuan teknis dinamis; para siswa dapat menyesuaikan diri di masyarakat. Hasil penelitian ini memberikan gambaran perlunya bagi warga berkebutuhan khusus untuk memiliki keterampilan kerja agar mereka dapat mengembangkan karir sesuai dengan potensi dan kondisi kebutuhannya.

Untuk mendorong dan mendasari perlunya pendidikan keterampilan kerja bagi warga berkebutuhan khusus di pedesaan, Goodenough (2006: 87) Obstacles to Program Effectiveness in Secondary Special Education (rintangan ke program efektivitas di dalam pendidikan khusus sekunder), mengembangkan model pendidikan keterampilan kerja yang diawali penelitian pengembangan dan survai. Penelitian Freeman, (1984: 28) Special education in the school community (pendidikan khusus di dalam sekolah masyarakat) menggambarkan, siswa yang mengalami kelainan ringan, masih layak untuk dipekerjakan atau mengambil bagian di dalam pendidikan bengkel kerja. Misalnya, melalui model pemagangan siswa untuk tinggal di rumah bengkel kerja. Mencermati konsep tersebut, model pendidikan keterampilan kerja bagi warga berkebutuhan khusus ini memberikan pelayanan kepada mereka melalui pelayanan keliling dalam pendidikan keterampilan. Setelah mereka selesai dan berhasil dididik keterampilan kerja sesuai pilihannya, warga berkebutuhan khusus akan diberikan kesempatan untuk magang beberapa hari di salah satu perusahaan atau industri kecil yang berdekatan dengan tempat tinggalnya.

Berbagai macam hasil penelitian yang telah diuraikan memberikan wacana untuk membuat model pendidikan keterampilan kerja, khususnya warga berkebutuhan khusus di pedesaan melalui pelayanan keliling. Penelitian ini dirancang dalam model pendidikan keterampilan kerja yang akan diawali melalui kegiatan penjaringan dan need assessment warga berkebutuhan khusus di pedesaan terpencil, pelaksanaan pendidikan keterampilan kerja, dan disertai praktik pemagangan di perusahaan atau industri kecil yang berada di pedesaan sekitar tempat tinggal warga berkebutuhan khusus.

\section{Metode Penelitian}

Penelitian dilakukan dengan pendekatan positivistik kuantitatif dan kualitatif secara longitudinal (Muhadjir, 2007: 33) dengan menggunakan model Research and Developmant $(R \& D)$ dari Borg and Gall (1989: 131). Dikatakan longitudinal (Muhadjir, 2007: 36) karena suatu penelitian sifatnya berkelanjutan untuk jangka waktu yang relatif panjang, mengikuti proses interaktif ragam variabel, dengan bertujuan untuk menjelaskan dan memahami kejadian yang diobservasi pada rentang waktu tertentu. Pendekatan ini juga disebut social survey design yang dipandu dengan struktur pertanyaan bersifat tertutup.

Penelitian dilaksanakan pada tahun 2008 2009, populasi penelitian wilayah kecamatan Gedangsari Kabupaten Gunungkidul. Sebagai sampel penelitian terdiri dari lima desa di Kecamatan Gedangsari (desa Sampang, Watugajah, Mertelu, Tegalrejo, dan Ngalang). Pada tataran selanjutnya menguji pengembangan model pendidikan keterampilan kerja bagi warga berkebutuhan khusus melalui pelayanan keliling berbasis partisipasi masyarakat pedesaan dalam beberapa tahapan pengembangan di wilayah pedesaan terpencil wilayah Kecamatan Gedangsari, Kabupaten Sleman, Daerah Istimewa 
Yogyakarta menggunakan siklus tahapan R\&D dari Borg and Gall (1989: 771-787).

Desain R\&D Borg \& Gall memberikan rujukan kepada peneliti bahwa untuk melakukan penelitian dan pengembangan perlu menetapkan 10 langkah utama seperti Gambar 1. berkebutuhan khusus, $\mathrm{X} 3$ kinerja organisasi dan manajemen model, X4 sarana, fasilitas dan pendanaan, X5 implementasi program aksi, X6 nilai manfaat model.

Keterampilan kerja warga berkebutuhan khusus dan efektivitas pelayanan model sebagai

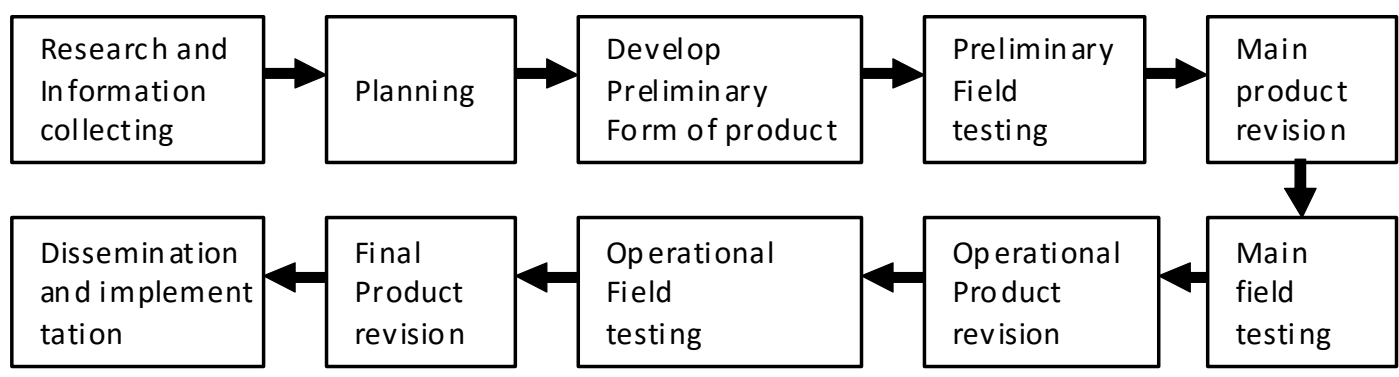

Gambar 1. Langkah-langkah R\&D Borg \& Gall (1989: 771-787)

Penelitian yang dirancang dengan menggunakan pendekatan longitudinal menguji secara teoritik maupun empirik tentang model pendidikan keterampilan kerja bagi warga berkebutuhan khusus melalui pelayanan keliling berbasis partisipasi masyarakat di pedesaan. Model ini dimaksudkan untuk mengukur tingkat efektivitas dan pengaruh hubungan antara variabel satu dengan yang lain. Adapun variabel yang dilibatkan dalam penelitian ini meliputi: 1) intensitas pelayanan model; terdiri dari subvariabel (a) partisipasi masyarakat, (b) partisipasi warga berkebutuhan khusus, (c) kinerja organisasi dan manajemen model, (d) sarana, vasilitas dan pendanaan, (e) implementasi program aksi, (f) nilai manfaat model; 2) keterampilan kerja warga berkebutuhan khusus: terdiri dari subvariabel a) keakuratan kerja dengan hasil yang tepat, (b) ketepatan waktu bekerja, (c) kesempurnaan kerja dengan hasil baik; 3) efektivitas pelayanan model; terdiri atas (a) tingkat penguasaan keterampilan, (b) kualitas produk yang dihasilkan, dan (c) pasar produk.

Mengacu pada tiga variabel pendidikan keterampilan kerja bagi warga berkebutuhan khusus melalui pelayanan keliling berbasis partisipasi masyarakat di pedesaan maka dapat disusun suatu model hipotetik yang memposisikan intensitas pelayanan model sebagai variabel laten eksogenous, yang terdiri dari subvariabel: (X1 partisipasi masyarakat, $X 2$ partisipasi warga variabel laten endogeneous (model struktural), yang terdiri dari subvariabel: Y1 keakuratan kerja dengan hasil yang dicapai, Y2 ketepatan waktu bekerja, Y3 kesempurnaan kerja dengan hasil baik, Y4 tingkat penguasaan keterampilan, Y5 kualitas produk, dan Y6 pasar produk. Selain itu, model ini juga menggambarkan efektivitas dan pengaruh hubungan variabel laten melalui variabel-variabel tampak.

Lokasi pengembangan model pendidikan keterampilan kerja bagi warga berkebutuhan khusus melalui model pelayanan keliling adalah wilayah Provinsi Daerah Istimewa Yoyakarta, Kabupaten Gunungkidul, Kecamatan Gedangsari, terdiri dari lima desa terpencil (Sampang, Watugajah, Mertelu, Tegalrejo, dan Ngalang).

Subjek coba adalah: 1) warga berkebutuhan khusus usia produktif (15-45 tahun) yang tinggal di pedesaan terpencil; 2) warga berkebutuhan khusus yang belum memiliki keterampilan kerja, memiliki minat dan motivasi belajar dengan dibuktikan melalui tindakan need assessment; 3) jenis kelamin, baik pria maupun wanita, diutamakan mereka belum keluarga, penganggur, belum memiliki keterampilan kerja; 4) tingkat dan jenis kelainan; kategori ringan, (tunanetra, bisu tuli, mental ringan, dan kelainan pisik).

Penelitian dirancang untuk dilakukan dalam dua proses tahapan. Tahap pertama melakukan penelitian pendahuluan di lapangan sesuai dengan rancangan metodologis hingga meng- 
hasilkan model pendidikan keterampilan kerja warga berkebutuhan khusus melalui pelayanan keliling, di pedesaan. Tahap kedua adalah penelitian pengembangan (development).

Data yang terkumpul dalam penelitian ini secara serempak dianalisis dengan teknik deskriptif kuantitatif dan kualitatif. Data kuantitatif diolah secara statistik dengan menerapkan program LISREL (Linear Structural Relations). Mengutip pendapat Fuad (2005: 46) program LISREL merupakan program komputer yang bertujuan membuat sistem persamaan struktural, yaitu untuk mengetahui efektivitas dan dampak pengembangan pendidikan keterampilan kerja bagi warga berkebutuhan khusus melalui uji coba model, sedangkan data kualitatif dianalisis menggunakan model interaktif.

\section{Hasil Penelitian dan Bahasan}

Distribusi normal dalam variabel menunjukan ada keragaman partisipasi yang seimbang, mulai dari yang kurang inten, cukup inten, sangat inten, sampai dengan sangat inten sekali. Dalam bentuk angka partisipasi masyarakat terukur pada kisaran sekor 8 sampai 20 , dengan sebaran berada di sekitar garis diagonal. Di sekitar garis diagonal berarti sekor data berada di sekitar nilai tengah atau terdistribusi seimbang sehingga dinyatakan normal. Beberapa yang jauh dari garis diagonal seperti sekor 8 dan 20 merupakan penyimpangan dari kenormalan dan dapat menyebabkan distribusi menjadi tidak normal, namun secara keseluruhan penyimpangan normal yang terjadi belum signifikan $(p>0.05)$ sehingga masih dalam toleransi distribusi normal.

Warga berkebutuhan khusus akibat keterbatasannya melakukan partisipasi dalam uji coba model ini sebagai peserta pendidikan keterampilan kerja. Mereka menunjukkan motivasi yang tinggi, mengharap mendapatkan pendidikan keterampilan kerja. Sehingga dirinya akan hidup lebih mandiri di tengah masyarakat.

Kinerja organisasi dan manajemen untuk mendukung uji coba model pendidikan keterampilan kerja di wilayah penelitian sudah terbentuk dengan payung hukum program PKBM (Pusat Kegiatan Belajar Masyarakat) yang ada di setiap desa. Organisasi dan manajemen uji coba model sampai pelaksanaan penelitian masih dalam kendali organisasi PKBM di setiap desa. Operasional kegiatan khususnya ketika tutor memberikan pelayanan pendidikan kepada penyandang cacat di pelosok-pelosok desa ada kordinasi dengan pengurus PKBM dan tim pelaksana model.

Implementasi program pendidikan keterampilan kerja di wilayah penelitian masih sangat terbatas. Hal ini dapat dilihat dari jumlah warga berkebutuhan khusus yang telah diberikan layanan pendidikan keterampilan kerja, jenis keterampilan kerja yang diberikan belum sesuai dengan kebutuhan permintaan atau yang diusulkan oleh warga berkebutuhan khusus. Keterampilan kerja yang diajarkan atau diujicobakan kepada warga berkebutuhan khusus sejumlah lima paket (kerajinan batik tulis, keterampilan membuat batako, kerajinan cetak sablon, keterampilan ternak kambing, dan keterampilan pertanian).

Mencermati temuan data tersebut menunjukkan bahwa nilai manfaat model pendidikan keterampilan kerja sangat positif. Hal ini dapat ditunjukkan dari tanggapan atau pendapat masyarakat yang terdiri dari pegawai kecamatan, perangkat desa, tokoh-tokoh masyarakat di lokasi desa uji coba model. Mereka umumnya sangat mengharapkan adanya model pendidikan keterampilan kerja ini, karena sangat menyentuh langsung khususnya warga masyarakat yang kekurangan atau warga berkebutuhan khusus yang tinggal di pedesaan terpencil yang selama ini belum tersentuh layanan pendidikan.

Uraian tersebut menunjukkan adanya keterbatasan kemampuan dan fisik penyandang cacat, ketika mereka menyelesaikan pekerjaan dan tidak dapat dituntut untuk menyelesaikan pekerjaan pada waktu tertentu secara tepat. Umumnya, mereka sangat lamban mengerjakan pekerjaan yang sifatnya motorik, baik itu motorik kasar maupun halus.

Temuan data menunjukkan bahwa hasil pendidikan yang telah diberikan tutor kepada warga berkebutuhan khusus menurut jenis dan kemampuannya sangat bervariatif, umumnya hasil pendidikan keterampilan kerja yang disampaikan belum maksimal. Hal ini disebabkan karena adanya keterbatasan yang dimiliki oleh warga berke- 
butuhan khusus, di samping itu penyajian materi dan sarana atau media pembelajaran sangat terbatas. Dampaknya adalah mempengaruhi kesempurnaan kerja dengan hasil yang kurang maksimal.

Keterbatasan yang dimiliki oleh warga berkebutuhan khusus, baik kemampuan pikir dan fisik mereka, berpengaruh terhadap penguasaan keterampilan kerja yang mereka hadapi. Berkaitan dan model keterampilan kerja yang diberikan kepada warga berkebutuhan khusus, ummunya belum dapat terkuasai dengan baik. Hal ini dapat ditunjukkan dengan waktu mengerjakan dan produk yang dihasilkan belum layak untuk dipasarkan. Jumlah kuantitas dan kualitas produk masih sangat terbatas, belum dapat memenuhi kebutuhan pangsa pasar. Perlu disadari, karena proses pembelajaran yang disampaikan kepada warga berkebutuhan khusus masih sangat terbatas. Pada sisi lain, perlu diperhatikan keterbatasan mereka, baik secara fisik maupun pikiran untuk mendapat pelayanan pendidikan keterampilan kerja secara berulang-ulang sampai dapat mengerjakan suatu jenis keterampilan kerja pada tingkatan kualitas produk yang dikehendaki pangsa pasar.

Sampai pada akhir kegiatan uji coba model, produk keterampilan kerja yang dihasilkan oleh para warga berkebutuhan khusus melalui pelayanan individu keliling di pedesaan terpencil, hasilnya belum maksimal. Berkaitan dengan pasar produk belum dapat terukur dan diketahui.

Secara keseluruhan, desain penelitian model Pendidikan Keterampilan Kerja yang dikembangkan di lima desa (Watugajah, Tegalrejo, Ngalang, Sampang, dan Mertelu) uji coba model mulai siklus pertama sampai ketiga dapat berjalan sesuai dengan tahap-tahap yang telah direncanakan.

Kondisi wilayah di Kecamatan Gedangsari di lima desa (Watugajah, Tegalrejo, Ngalang, Sampang, dan Mertelu) tergolong wilayah IDT (Inpres Desa Tertinggal), memiliki karakteristik yang unik sebagai kriteria desa terpencil. Meskipun demikian, kelima desa tersebut umumnya memiliki potensi yang baik sebagai sumber daya lingkungan desa yang dapat dimanfaatkan untuk pengembangan model pendidikan keterampilan kerja, dalam penanganan warga berkebutuhan khusus usia produktif untuk usaha mandiri di pedesaan.
Respon masyarakat yang diwakili oleh tutor dan tim pelaksana model terhadap program Pendidikan Keterampilan Kerja relatif tinggi, terbukti dengan adanya program pelatihan tutor yang dikirim masing-masing desa hanya dijatah 6 orang sehingga seluruhnya 30 orang, tetapi dikirim sebanyak 45 orang, dan semuanya mengikuti pelatihan secara antusias sampai selesai. Keterlibatan perangkat kecamatan dan desa saat pembukaan pelatihan, menunjukkan respon masyarakat setempat cukup baik.

Jumlah warga berkebutuhan khusus usia produktif/dewasa yang berhasil dijaring dalam penelitian ini berjumlah 194 orang. Penyebarannya menunjukkan; desa Watugajah 27 orang, desa Tegalrejo 43 orang, desa Ngalang 45 orang, desa Sampang 43 orang, dan desa Mertelu 36 orang. Desa Ngalang menduduki yang tertinggi (45 orang) dan terendah desa Watugajah (27 orang). Angka ini berkorelasi dengan karakteristik desa. Semakin maju desa akan semakin berkurang jumlah warga berkebutuhan khusus, dan sebaliknya.

Dari segi sosialisasi kegiatan model Pendidikan Keterampilan Kerja sampai akhir penelitian ini dapat disimpulkan bahwa di lima desa tersebut cukup lancar. Hal ini didukung oleh fakta bahwa dari sejumlah tutor di masing-masing desa telah melakukan aktivitas pendidikan keterampilan kerja kepada para warga berkebutuhan khusus, berhasil merekrut tokoh-tokoh masyarakat dan perangkat desa yang bersedia menjadi pengurus kegiatan model Pendidikan Keterampilan Kerja bagi warga berkebutuhan khusus di pedesaan.

Untuk kelancaran kegiatan model Pendidikan Keterampilan Kerja perlu didukung adanya organisasi di tingkat desa. Pengurus organisasi tim model terdiri dari para tutor, tokoh masyarakat, Kepala Dusun, dan Kepala Desa sebagai pelindungnya. Semua organisasi pelaksana model di lima desa wilayah penelitian telah terbentuk. Sampai pada akhir penelitian ini, organisasi pelaksana model semuanya telah bekerja secara proporsional.

Menentukan skala prioritas materi dan jenis keterampilan kerja sangat perlu. Hal ini mempertimbangkan anggaran biaya, kemampuan warga berkebutuhan khusus, kesesuaian dengan 
lingkungan pedesaan, bahan dan suku cadang untuk kegiatan, dan pangsa pasar atau jual beli produk yang dibuat. Karena itu, setelah para tutor dan warga berkebutuhan khusus mendapat materi dasar-dasar keterampilan kerja, skala prioritas materi keterampilan kerja yang diajarkan adalah kerajinan anyaman bambu, keterampilan cetak batako, keterampilan beternak kambing, kerajinan batik tulis, dan keterampilan pertanian.

Menentukan komponen pengembangan pendanaan dalam suatu kegiatan sangat penting. Dalam menunjang program pengembangan model, perlu adanya stimuli dana bagi desa-desa yang melaksanakan model pendidikan keterampilan kerja. Alternatif kucuran dana diperoleh dari: swadaya masyarakat, khususnya mereka yang ekonominya berhasil, subsidi dari instansi/lembaga terkait, LSM, PNPK (Program Nasional Penanggulangan Kemiskinan), masyarakat yang peduli kepada warga berkebutuhan khusus.

Hasil temuan siklus pertama menunjukkan bahwa beberapa komponen model telah berjalan dengan baik meskipun belum optimal. Hal ini disebabkan karena penelitian ini merupakan penelitian baru yakni pengembangan model yang dilakukan secara bersama-sama dengan masyarakat. Karena itu butuh waktu yang lama, apalagi yang ditangani adalah masalah warga berkebutuhan khusus. Dalam banyak kasus, masyarakat umumnya cenderung pasif dan kurang positif, sehingga pembinaan dan pemantauan setiap komponen perlu terus dilakukan meskipun kegiatan penelitian ini telah berakhir.

Temuan siklus kedua dalam hal tingkat pengorganisasian model, masih ada yang masuk kategori kurang baik, tampaknya karena berkaitan dengan tingkat kepekaan dan kesadaran para aparat/pamong desa setempat. Hasil pengamatan lapangan mengisyaratkan bahwa model pendidikan keterampilan kerja kalau ingin berhasil, perlu dukungan penuh dari pamong desa, karena peran pimpinan formal di masyarakat masih cukup dominan.

Temuan siklus ketiga tentang efektivitas pendidikan keterampilan kerja, banyak menghadapi kendala dan tampaknya kendala itu tidak mudah dipecahkan karena terkait dengan berbagai faktor, misalnya jenis berkebutuhan khusus berbeda-beda, tempat tinggal berjauhan, sarana transportasi tidak mudah, jenis keterampilan bermacam-macam, motivasi warga berkebutuhan khusus berbeda-beda. Kondisi ini semua menyulitkan pengelola program khususnya para tutor untuk dapat memaksimalkan semua komponen yang dikembangkan dalam model pendidikan keterampilan kerja bagi warga berkebutuhan khusus di pedesaan terpencil.

Temuan siklus ketiga tentang dampak program model memang belum maksimal. Data kuantitatif yang diperoleh dirasa cukup menggambarkan seberapa besar dampak, atau paling tidak getaran program pendidikan keterampilan kerja dalam skala desa, dan Kecamatan, program ini dapat diterima secara baik di semua pihak. Khususnya dampak yang dirasakan oleh warga berkebutuhan khusus tidak sekedar secara fisik dapat memiliki keterampilan kerja atau skil, justru dampak secara psikologis sangat mereka rasakan. Secara psikologis mereka merasa diperhatikan, dihargai, hal ini menumbuhkan semangat hidup, semnagat berkarya, dan hidup mandiri di tengah masyarakat tanpa selalu menggantungkan orang lain.

Berdasarkan rumusan masalah, analisis dan bahasan terhadap temuan hasil penelitian tentang model pendidikan keterampilan kerja bagi warga berkebutuhan khusus melalui pelayanan keliling berbasis partisipasi masyarakat pedesaan dapat ditarik simpulan seperti berikut ini.

Dalam fungsi pertama nilai t-hitung lebih dari 2 sebesar 3.2502, nilai t-hitung $>2$ menunjukkan pengaruh eksogen dalam fungsi, adalah signifikan. Berdasarkan temuan ini dapat dijelaskan bahwa keterampilan subjek dapat berubah dengan arah positif sesuai dengan berubahnya intensitas, yaitu bila dapat diupayakan suatu intensitas yang meningkat maka keterampilan warga berkebutuhan khusus juga meningkat; besarnya perubahan yang dikontribusikan oleh intensitas sebesar 22,38\%.

Untuk dapat melakukan perubahan itu, upaya yang dapat dilakukan adalah melalui pengendalian terhadap partisipasi masyarakat, partisipasi warga berkebutuhan khusus, kinerja organisasi dan manajemen, sarana-fasilitaspendanaan, implementasi program aksi, dan nilai manfaat model. Upaya yang dapat dilakukan adalah melalui pengendalian terhadap partisipasi 
masyarakat, partisipasi warga berkebutuhan khusus, kinerja organisasi dan manajemen, sarana-fasilitas-pendanaan, implementasi program aksi, dan nilai manfaat model.

Dalam fungsi kedua juga diperoleh nilai thitung lebih dari 2, yaitu untuk eksogen intensitas sebesar 4,845 dan keterampilan sebesar 4,114. Berarti pengaruh keduanya signifikan terhadap efektivitas. Besarnya perubahan yang dapat dijelaskan oleh keduanya sebesar $79,87 \%$. Untuk menjaga keterampilan selain melaui intensitas juga dapat dilakukan melalui pelatihan agar diperoleh keakuratan kerja, ketepatan waktu bekerja, dan kesempurnaan kerja dengan hasil optimal.

Dalam model yang diuji, digambarkan intensitas dapat langsung mempengaruhi efektivitas, dan secara tidak langsung melalui keterampilan. Secara langsung mampu menjelaskan sebesar $0,5882^{2}=34,59 \%$, dan secara tidak langsung melalui keterampilan sebesar $0,2128^{2}=4,52 \%$. Mencermati kedua hal tersebut terlihat pengaruh langsungnya lebih besar dibandingkan melalui keterampilan, namun hal ini bukanlah keterampilan tidak berarti, karena sudah terbukti signifikan kontribusinya terhadap efektivitas.

Secara keseluruhan, desain penelitian model pendidikan keterampilan kerja bagi warga berkebutuhan khusus melalui pelayanan keliling berbasis partisipasi masyarakat yang dikembangkan di lima desa (Watugajah, Tegalrejo, Ngalang, Sampang, dan Mertelu) uji coba model mulai siklus pertama sampai siklus ketiga dapat berjalan sesuai dengan tahap-tahap yang telah direncanakan.

\section{Simpulan dan Saran}

\section{Simpulan}

Untuk dapat melaksanakan pendidikan keterampilan kerja bagi warga berkebutuhan khusus melalui pelayanan keliling di pedesaan, perlu didukung adanya organisasi di tingkat desa. Pengurus organisasi tim model terdiri dari para tutor, tokoh masyarakat, Kepala Dusun, dan Kepala Desa sebagai pelindungnya. Semua organisasi pelaksana model di lima desa (Watugajah, Tegalrejo, Ngalang, Sampang, dan Mertelu) wilayah penelitian telah terbentuk.
Sampai pada akhir penelitian ini, organisasi pelaksana model semuanya telah bekerja secara proporsional.

Kegiatan diawali menentukan skala prioritas materi dan jenis keterampilan kerja sangat perlu. Hal ini mempertimbangkan anggaran biaya, kemampuan warga berkebutuhan khusus, kesesuaian dengan lingkungan pedesaan, bahan dan suku cadang untuk kegiatan, dan pangsa pasar atau jual beli produk yang dibuat. Karena itu, setelah para tutor dan warga berkebutuhan khusus mendapat materi dasar-dasar keterampilan kerja, skala prioritas materi keterampilan kerja yang diajarkan adalah kerajinan anyaman bambu, keterampilan cetak batako, keterampilan beternak kambing, kerajinan batik tulis, dan keterampilan pertanian.

Langkah selanjutnya menentukan komponen pengembangan pendanaan dalam suatu kegiatan sangat penting. Dalam menunjang program pengembangan model, perlu adanya stimuli dana bagi desa-desa yang melaksanakan model pendidikan keterampilan kerja. Alternatif kucuran dana diperoleh dari: swadaya masyarakat, khususnya mereka yang ekonominya berhasil, subsidi dari instansi/lembaga terkait, LSM, PNPK (Program Nasional Penanggulangan Kemiskinan), masyarakat yang peduli kepada warga berkebutuhan khusus.

Hasil temuan siklus pertama menunjukkan bahwa beberapa komponen model telah berjalan dengan baik meskipun belum optimal. Hal ini disebabkan karena penelitian ini merupakan penelitian baru yakni pengembangan model yang dilakukan secara bersama-sama dengan masyarakat. Karena itu butuh waktu yang lama, apalagi yang ditangani adalah masalah warga berkebutuhan khusus. Dalam banyak kasus, masyarakat umumnya cenderung pasif dan kurang positif, sehingga pembinaan dan pemantauan setiap komponen perlu terus dilakukan meskipun kegiatan penelitian ini telah berakhir.

Temuan siklus kedua dalam hal tingkat pengorganisasian model, masih ada yang masuk kategori kurang baik, tampaknya karena berkaitan dengan tingkat kepekaan dan kesadaran para aparat/pamong desa setempat. Hasil pengamatan lapangan mengisyaratkan bahwa model pendidikan keterampilan kerja kalau ingin berhasil, 
perlu dukungan penuh dari pamong desa, karena peran pimpinan formal di masyarakat masih cukup dominan.

Temuan siklus ketiga tentang efektivitas pendidikan keterampilan kerja, banyak menghadapi kendala dan tampaknya kendala itu tidak mudah dipecahkan karena terkait dengan berbagai faktor, misalnya jenis berkebutuhan khusus berbeda-beda, tempat tinggal berjauhan, sarana transportasi tidak mudah, jenis keterampilan bermacam-macam, motivasi warga berkebutuhan khusus berbeda-beda. Kondisi ini semua menyulitkan pengelola program khususnya para tutor untuk dapat memaksimalkan semua komponen yang dikembangkan dalam model pendidikan keterampilan kerja bagi warga berkebutuhan khusus di pedesaan terpencil.

Temuan siklus selanjutnya tentang dampak program model memang belum maksimal. Data kuantitatif yang diperoleh dirasa cukup menggambarkan seberapa besar dampak, atau paling tidak getaran program pendidikan keterampilan kerja dalam skala desa, dan Kecamatan, program ini dapat diterima secara baik di semua pihak. Khususnya dampak yang dirasakan oleh warga berkebutuhan khusus tidak sekedar secara fisik dapat memiliki keterampilan kerja atau skil, justru dampak secara psikologis sangat mereka rasakan. Secara psikologis mereka merasa diperhatikan, dihargai, hal ini menumbuhkan semangat hidup, semnagat berkarya, dan hidup mandiri di tengah masyarakat tanpa selalu menggantungkan orang lain.

\section{Saran}

Need assesment perlu dilakukan lebih eksploratif dan komprehensif dengan melibatkan berbagai stakeholders sehingga pelaksanaan model pendidikan keterampilan kerja dapat dirancang sesuai dengan tuntutan yang sedang berkembang; pada sisi lain kesesuaian antara kurikulum dan peluang kerja dapat berjalan seirama, sehingga peluang bagi peserta didik yang telah berhasil mengikuti pendidikan keterampilan kerja dapat bersaing pada pasaran kerja.
Mengintensifkan penyebarluasan informasi program pendidikan keterampilan kerja agar pelayanan mampu menjangkau wilayah yang lebih luas melalui berbagai jaringan, serta lebih mengintensifkan koordinasi dengan institusi sosial Kabupaten Gunung Kidul, sehingga sasaran target garapan warga berkebutuhan khusus yang tinggal di pedesaan terpencil dapat dipenuhi.

Untuk mempertinggi keberhasilan penyaluran melalui sistem open employment, perlu penambahan aspek persyaratan peserta didik yaitu aspek motivasi dan minat terhadap pekerjaan, aspek pribadi yang menyangkut moral dan sifatsifat yang diperlukan untuk suatu pekerjaan, serta aspek intelektual, yaitu kemampuan berpikir dan tingkat pengetahuan yang dimiliki.

Perlu disusun kurikulum untuk setiap jenis keterampilan yang dapat diberlakukan secara nasional. Tim pelaksana model menawarkan paket-paket program inti dan pilihan yang sesuai dengan kebutuhan tuntutan pasar, sehingga peserta didik lebih fleksibel dalam persaingan pasaran tenaga kerja. Beberapa jenis keterampilan yang prospektif perlu dikembangkan dan dibuka, untuk jenis keterampilan yang kurang mampu menembus pasar kerja sementara ditangguhkan.

Perlu peningkatan kualitas tutor melalui pengembangan pengetahuan dan teknologi terbaru yang menjadi tuntutan pasaran ketenagakerjaan saat ini dengan merancang program pendidikan keterampilan kerja yang sesuai dengan kondisi pasaran ketenaga-kerjaan.

Tolok ukur keberhasilan model sebaiknya bukan paket waktu, tetapi didasarkan pada penguasaan keterampilan dan kesiapan warga berkebutuhan khusus untuk bekerja. Hal ini untuk mengantisipasi adanya image bahwa tim pelaksana model hanya merupakan tempat untuk pelatihan kerja, tetapi tidak memiliki target ketika berakhirnya pendidikan keterampilan kerja; peserta didik telah mampu memiliki keterampilan yang benar-benar diperlukan masyarakat. 


\section{Pustaka Acuan}

Arnold. Nancy L. and Tom Seekins. 2006. Self-employment in vocational, rehabilitation: Lessons from Rural America Self-Employment Vocational Rehabilitation Closure: An Examination of State Policies

Boe Erling E . 2006. Long-term trends in the national demand, supply, and shortage of special education teachers, The Journal of Special Education. Bensalem: Fall 2006.Vol.40, Iss. 3 pg. 138, 13 pgs.

Borg R Walter, Gall Mredith D. 1989. Educational research, an intruduction, Routledge, New York.

Bullis Michael, Paul Yovanoff. 2006. Idle hands: community employment experiences of formerly incarcerated youth. Journal of Emotional and Behavioral Disorders.

Vol.14, Iss. 2; pg. 71, 15 pgs

Departemen Sosial RI. 2005. Penyebaran penduduk di Indonesia, Jakarta: Laporan Penelitian.

Etscheidt Susan. 2006. Least restrictive and natural environments for young children with disabilities, topics in early childhood special education. Austin: Fall 2006. Vol. 26, Iss.3; pg. 167, 12 pgs.

Freire Paulo. Pengantar: F. Danuwinata. 2002. Pendidikan kaum tertindas. Jakarta: LP3ES.

Freeman, RD. 1984. Can't your child hear? a guide for those who care about deaf children, Baltimore: University Park Press.

Goble, Frank G. 1987. Madzab ketiga psikologi humanistik Abraham Maslow, (terjemahan), Yogyakarta: PT. Kanisius.

Goodenough, FL. 1996. Exceptional children, New York: Appleton, Century Croft Inc.

Hall Sharon, Taymans \& Juliana M Defur. 1995. Vocational education special education social services, Publication title: Exceptional Children. Reston: Sep 1995. Vol. 62, Iss. 1; pg. 38

Harvey Michael W . 2001. Vocational-technical education A logical approach to dropout prevention for secondary special education, Preventing School Failure. Washington: Spring 2001.Vol.45, Iss. 3; pg. 108,6 pgs

Haryanto. 2005. Model pendidikan kecakapan hidup bagi penyandang cacat di pedesaan, Laporan Penelitian, PLB FIP UNY.

Haryanto. 2007. Model rehabilitasi penyandang cacat di pedesaan, Laporan Penelitian, PLB FIP UNY.

Indiana Chris Zirkle. 1998. Perceptions of vocational educators and human resource/training and development professionals regarding skill dimensions of school-to-work transition programs, Current Editor: Kirk Swortzel: kswortzel @ais.msstate.edu Volume 15, Number 1 Fall 1998

Imam Ghazali, Fuad. 2005. Structural equation modeling teori, konsep, dan aplikasi dengan program LISREL 8.54, Semarang: Badan Penerbit Universitas Diponegoro.

Jenny Corbett Jennie Kitteringham Bernie Mc Anespie. 1999. Vocational education and training to support the transition of young people with learning disabilities to paid employment, University of London, UK Finland 22 - 25 September 1999

Laughlin Margaret Mc. 2003. Special education in the school community, University of Maryland at College Park P.O. Box 1492 Washington, DC 20013 Volume 2, No. 2, 2003

Muhadjir Noeng. 2007. Metodologi keilmuan paradigma kualitatif, kuantitatif, dan mixed. Yogyakarta: Rake Sarasin.

Peg Lamb. 2003. The role of the vocational rehabilitation counselor in procuring technology to facilitate success in postsecondary education for youth with disabilities. Journal of Special Education Technology. Nashville: Fall 2003. Vol. 18, Iss.4; pg.53, 12 pgs.

Polloway, EA \& Patto, JR. 1993. Strategies for teaaching learners with special needs, New York: Macmillan Publishing Co. 